\title{
ANALISIS PELAKSANAAN STIMULASI DAN DETEKSI DINI TUMBUH KEMBANG ANAK OLEH KADER POSYANDU (Studi Pada Kader Posyandu di Wilayah Kerja Puskesmas Dukuh Menanggal Surabaya)
}

\author{
Setiawandari \\ Prodi DIII Kebidanan Universitas PGRI Adi Buana Surabaya \\ Setiawandari7@gmail.com
}

\begin{abstract}
ABSTRAK
Upaya kesehatan yang dilakukan sejak anak masih di dalam kandungan sampai lima tahun pertama kehidupannya, ditujukan untuk mempertahankan kelangsungan hidupnya sekaligus meningkatkan kualitas hidup anak agar mencapai tumbuh kembang optimal baik fisik, mental, emosional maupun sosial serta memiliki inteligensi majemuk sesuai dengan potensi genetiknya. Penilaian pertumbuhan dan perkembangan dapat dilakukan sedini mungkin sejak anak dilahirkan. Deteksi dini merupakan upaya penjaringan yang dilaksanakan secara komprehensif untuk menemukan penyimpangan tumbuh kembang dan mengetahui serta mengenal faktor resiko pada balita, yang disebut juga anak usia dini. Sehingga upaya pencegahan, stimulasi, penyembuhan serta pemulihan dapat diberikan dengan indikasi yang jelas pada masa-masa kritis proses tumbuh kembang. Upaya-upaya tersebut diberikan sesuai dengan umur perkembangan anak, dengan demikian dapat tercapai kondisi tumbuh kembang yang optimal.

Tujuan penelitian adalah menganalisis pelaksanaan stimulasi dan deteksi dini tumbuh kembang anak oleh kader posyandu. Jenis penelitian ini adalah diskriptif kualitatif dengan menggunakan study kasus. Teknik pengambilan sampel menggunakan purposive sampling, sedangkan teknik pengumpulan data primer dilakukan dengan cara wawancara mendalam (indepth interview) kepada kader posyandu di wilayah Puskesmas Kecamatan Dukuh Menanggal Surabaya, sedangkan triangulasi didapatkan dari orang tua bayi balita dan Bidan penanggungjawab wilayah.

Hasilnya kurangnya pengetahuan kader tentang kegiatan stimulasi tumbuh kembang dalam buku KIA, begitu juga pengetahuan kader tentang deteksi dini tumbuh kembang juga kurang. Pelaksanaan stimulasi perkembangan anak hanya sebatas bertanya pada ibu tidak menceklis sesuai dalam buku KIA, sedangkan pelaksanaan deteksi dini pertumbuhan sudah baik dengan cara pengukuran berat badan, tinggi badan dan lingkar kepala anak. Jika menemukan penyimpangan segera merujuk ke Bidan atau Puskesmas. Kesimpulan perlu dilakukan pelatihan stimulasi dan deteksi dini tumbuh kembang anak pada kader posyandu dan sosialisasi tentang kegiatan yang terdapat dalam buku KIA.
\end{abstract}

Kata Kunci : Kader Posyandu, Stimulasi dan Deteksi Dini Tumbuh Kembang Anak

\section{PENDAHULUAN $\backslash$}

Pembangunan kesehatan sebagai bagian dari upaya membangun manusia seutuhnya antara lain diselenggarakan melalui upaya kesehatan anak yang dilakukan sedini mungkin sejak anak masih di dalam kandungan. Upaya kesehatan ibu yang dilakukan sebelum dan semasa hamil hingga melahirkan, ditujukan untuk menghasilkan keturunan yang sehat dan lahir dengan selamat (intact survival). Upaya kesehatan yang dilakukan sejak anak masih di dalam kandungan sampai lima tahun pertama kehidupannya, ditujukan untuk mempertahankan kelangsungan hidupnya sekaligus meningkatkan kualitas hidup anak agar mencapai tumbuh kembang optimal baik fisik, mental, emosional maupun sosial serta memiliki inteligensi majemuk sesuai dengan potensi genetiknya. Tidak semua bayi terlahir sehat. Beberapa bayi lahir dengan gangguan pada masa prenatal (kehamilan), proses persalinan, serta pasca kelahiran. Keadaan ini menyebabkan bayi mempunyai risiko tinggi untuk mengalami gangguan tumbuh kembang dibandingkan dengan bayi yang lahir normal. 
Penilaian

pertumbuhan

dan perkembangan dapat dilakukan sedini mungkin sejak anak dilahirkan. Deteksi dini merupakan upaya penjaringan yang dilaksanakan secara komprehensif untuk menemukan penyimpangan tumbuh kembang dan mengetahui serta mengenal faktor resiko pada balita, yang disebut juga anak usia dini. Sehingga upaya pencegahan, stimulasi, penyembuhan serta pemulihan dapat diberikan dengan indikasi yang jelas pada masa-masa kritis proses tumbuh kembang. Upaya-upaya tersebut diberikan sesuai dengan umur perkembangan anak, dengan demikian dapat tercapai kondisi tumbuh kembang yang optimal (Tim Dirjen Pembinaan Kesmas, 1997).

Menurut Depkes RI (2006) yang dikutip oleh Kholifah menyatakan bahwa $16 \%$ balita Indonesia mengalami gangguan perkembangan, baik perkembangan motorik halus dan kasar, gangguan pendengaran, kecerdasan kurang dan keterlambatan bicara. Pada tahun 2010 di Rumah Sakit Umum Dr. Soetomo Surabaya, dijumpai 133 kasus pada anak remaja dengan gangguan perkembangan motorik kasar maupun halus (Kholifah, SN. 2014). Hal serupa juga disampaikan oleh dr.Mira Irmawati, SpA (K) konsultan tumbuh kembang anak RSUD dr Soetomo bahwa sebanyak $40 \%$ dari 80 pasien balita yang berkunjung tiap hari di Poli Tumbuh Kembang Anak RSUD dr Soetomo mengalami gangguan bicara dan bahasa (sehat.link, 2014).

Hasil survey awal dengan wawancara pada beberapa kader posyandu di wilayah Kecamatan Dukuh Menanggal, mengatakan bahwa mereka mengetahui bahwa di dalam Buku KIA ada materi selain pemantauan pertumbuhan anak juga tentang cara merangsang perkembangan anak dari umur 0-3 bulan sampai umur 3-5 tahun, jika pada usia yang diharapkan bayi atau anak belum bisa melakukan sesuatu yang seharusnya, maka kader atau orang tua diharapkan membawa bayi anak ke tenaga kesehatan. Stimulasi dan skrining ini jarang dilaksanakan, karena walaupun kader posyandu mengetahui, mereka beranggapan bahwa melakukan stimulasi dan skrining tumbuh kembang adalah tugas dari orang tua masingmasing.

Rumusan masalah adalah bagaimanakah pengetahuan kader tentang stimulasi dan deteksi dini tumbuh kembang anak serta bagaimanakah pelaksanaan stimulasi dan skrining/deteksi dini penyimpangan tumbuh kembang anak di wilayah kerja posyandu Kecamatan Dukuh Menanggal?

\section{METODE PENELITIAN}

Jenis penelitian ini adalah penelitian kualitatif yang disajikan secara deskriptif eksplorasi melalui observasi dan wawancara mendalam.Sampel penelitian ini adalah kader posyandu di wilayah kerja Posyandu Puskesmas Dukuh Menanggal Surabaya.Teknik sampel menggunakan purposive sampling,Teknik pengumpulan data primer dilakukan dengancara wawancara mendalam (indepth interview).

\section{HASIL PENELITIAN}

\section{Diskripsi Pengetahuan Kader Posyandu Tentang Stimulasi Tumbuh Kembang Anak}

Berdasarkan hasil indepth interview kepada kader posyandu dan informan triangulasi serta melakukan observasi terhadap pelaksanaan stimulasi dan deteksi dini di beberapa posyandu di Kelurahan Dukuh Menanggal, maka dapat diuraikan hasil penelitian bahwa sebagian besar informan mengetahui tentang buku KIA, tetapi kurang memahami isinya.

Buku KIA merupakan alat untuk mendeteksi secara dini adanya gangguan atau masalah kesehatan ibu dan anak, alat komunikasi dan penyuluhan dengan informasi yang penting bagi ibu, keluarga dan masyarakat mengenai pelayanan kesehatan ibu dan anak termasuk rujukannya dan paket (standar) pelayanan KIA, gizi, imunisasi dan tumbuh kembang balita. Sosialisasi tentang buku KIA dan kegiatan didalamnya harus sering dilakukan, mengingat tugas kader di meja empat adalah 2 diantaranya menilai perkembangan balita sesuai umur berdasarkan buku KIA, jika ditemukan keterlambatan, kader mengajarkan ibu untuk memberikan rangsangan dirumah dan memberikan penyuluhan sesuai dengan kondisi pada saat itu. Di dalam buku KIA yang dilakukan kader posyandu dalam kegiatan stimulasi tumbuh kembang anak adalah menanyakan dan mencontreng di kolom yang telah disediakan perkembangan yang telah anak dapatkan berdasarkan usia. Jika didapatkan salah satu dari perkembangan anak yang tidak sesuai dengan usia maka kader posyandu diharapkan mampu melakukan rujukan.

Adapun pengetahuan kader tentang stimulasi perkembangan yang ada dalam buku KIA adalah tiga dari lima kader kesehatan 
posyandu mengasumsikan bahwa stimulasi yang dilakukan pada anak adalah pemberian makanan sehat untuk pertumbuhan anak. Tetapi 4 orang kader kesehatan juga mengasumsikan bahwa stimulasi tumbuh kembang anak adalah dengan pemberian mainan.

Seperti yang disampaikan oleh dr.Yulia Suherlina (2011) bahwa pertumbuhan danperkembangan merupakan dua peristiwa yang berbeda tetapi tidak bisa dipisahkan. Pertumbuhan merupakansuatu perubahan dalamukuran tubuh dan merupakan sesuatu yang dapat diukur seperti tinggi badan, berat badan, lingkar kepala yang dapat dibaca pada buku pertumbuhan. Sedangkanperkembanganlebihditujukanpadakemat angan fungsi alat-alat tubuh. Seperti, kaki untuk melompat (gerakan kasar), jari-jari tangan untuk menulis, mengancingkan baju (gerakanhalus), pemahaman(bagaimanaanak

belajardari

lingkungannyauntuk mengerti anggotatubuh, warna), bicara (anak mampu mengungkapkan sesuatu yang dimaksud) dan sosialisasi.

Untuk memantau tumbuh kembang anak dengan baik maka para orang tua, tenaga kesehatan, pendidik dan kader kesehatan perlu mengetahui sekaligus mengenal ciri-ciri serta prinsip tumbuh kembang anak, hal ini akan memudahkan kita dalam memberikan stimulasi tumbuh kembang sesuai dengan yang dibutuhkan dan diharapkan anak untuk mencapai tumbuh kembang optimal. Stimulasi adalah kegiatan merangsang kemampuan dasar anak umur 0-6 tahun agar anak tumbuh dan berkembang secara optimal. Kegiatan stimulasi datang dari lingkungan luar anak antara lain berupa latihan dan bermain, dan didalam buku KIA (Kemenkes RI. 2015. Hal 66-83) telah ada panduaan untuk kader kesehatan dan keluarga dalam hal pemberian stimulasi pada anak usia 0-6 tahun. Tetapi buku panduan tidak akan bermanfaat jika kader dan orang tua tidak pernah membuka dan mengetahui kegiatan didalamnya. Kader kesehatan atau kader posyandu mempunyai peran penting dalam memberikan pembinaan kepada orang tua dan stimulasi tumbuh kembang anak pada buka posyandu. Sebelum kader kesehatan tersebut bisa memberikan pembinaan kepada orang tua anak, para kader harus mendapatkan penyuluhan dan pelatihan terlebih dahulu tentang pertumbuhan perkembangan anak, ciri-ciri dan prinsip tumbuh kembang anak.
Kurangnya pemahaman pengetahuan kader tentang stimulasi tumbuh kembang anak dalam hal ini bisa jadi disebabkan kader posyandu tersebut belum pernah mendapatkan pelatihan tentang stimulasi tumbuh kembang anak, kondisi ini didukung dengan data bahwa dari lima kader yang diwawancarai, belum ada kader yang pernah mendapatkan pelatihan tentang bagaimana menstimulasi tumbuh kembang anak. Sebagian besar kader mendapatkan pembinaan berupa penyuluhan dari petugas Puskesmas sebanyak 1 bulan sekali. Penyuluhan yang mereka dapat tidak spesifik tentang stimulasi tumbuh kembang anak, melainkan dengan tema yang berganti-ganti.

Menurut Direktorat Bina Gizi Masyarakat (1998), bahwa pengetahuan keterampilan kader dipengaruhi oleh adanya pembinaan, dengan pembinaan kader akan meningkatkan pengetahuan, aktivitas dan keterampilan kader dalam menjalankan tugasnya. Pelatihan stimulasi dan deteksi dini pada kader posyandu sangat penting diberikan, mengingat kader adalah merupakan salah satu unsur yang memiliki peranan penting dalam pelayanan kesehatan dimasyarakat dan pemberi layanan BKB. Hal ini sejalan dengan hasil penelitian Aticeh (2015) yang menunjukkan bahwa knowledge $(\mathrm{p}=0.001$ $\mathrm{OR}=5,29)$ sehingga dapat disimpulkan bahwa pengetahuan kader sangat diperlukan dalam meningkatkan motivasi kader dalam melakukan stimulasi dan deteksi dini tumbuh kembang. Seseorang yang memiliki pengetahuan tentang pertumbuhan dan perkembangan anak akan menimbulkan motivasi pentingnya melakukan stimulasi dan deteksi dini tumbuh kembang pada balita.

\section{Diskripsi Pengetahuan Kader Posyandu Tentang Deteksi Dini Tumbuh Kembang Anak}

Dari hasil indept intervew kelima kader posyandu diatasdapat diketahui bahwa pengetahuan kader posyandu tentang deteksi dini tumbuh kembang anak masih kurang, sebagian besar kader mengasumsikan bahwa deteksi dini tumbuh kembang anak hanya dilihat dari pertumbuhan yaitu berat badan anak yang tidak naik. Sedangkan hanya satu kader posyandu yang menjawab benar. Penyimpangan pertumbuhan juga diasumsikan hanya dari berat badan anak yang tetap atau tidak naik timbangannya, tetapi dari tinggi badan berdasarkan usia dan pengukuran lingkar kepala dan pengukuran 
lingkar lengan atas masih jauh dari pengetahuan para kader posyandu.

Menurut Kemenkes RI (2013), deteksi dini tumbuh kembang anak adalah kegiatan/ pemeriksaan untuk menemukan secara dini adanya penyimpangan tumbuh kembang pada balita dan anak prasekolah. Dengan ditemukan secara dini penyimpangan/ masalah tumbuh kembang anak, maka intervensi akan lebih muda dilakukan, tenaga kesehatan juga mempunyai waktu dalam membuat rencana tindakan/ intervensi yang tepat, terutama ketika harus melibatkan ibu/ keluarga. Bila penyimpangan terlambat diketahui, maka intervensinya akan lebih sulit dan hal ini akan berpengaruh pada tumbuh kembang anak. Deteksi dini penyimpangan anak dilakukan di semua tingkat pelayanan. Di tingkat pelayanan keluarga atau masyarakat, deteksi dini dilaksanakan oleh orang tua dan kader kesehatan/ BKB/ TPA dengan menggunakan bantuan alat buku KIA.

Kader kesehatan mempunyai peran yang cukup penting dalam menemukan penyimpangan pertumbuhan dan perkembangan pada anak, karena pada meja 4 kegiatan posyandu, tugas kader posyandu adalah : 1) Menjelaskan data KIA / KMS berdasarkan hasil timbang; 2) Menilai perkembangan balita sesuai umur berdasarkan buku KIA. Jika ditemukan keterlambatan, kader mengajarkan ibu untuk memberikan rangsangan dirumah; 3) Memberikan penyuluhan sesuai dengan kondisi pada saat itu; 4) Memberikan rujukan ke Puskesmas, apabila diperlukan (Depkes RI, 2005).

Berdasarkan peran kader tersebut diatas, makahal-hal yang bisa dilakukan kader dalam deteksi dini pertumbuhan anak / balita antara lain : 1) Penimbangan berat badan; 2) Pengukuran tinggi badan; 3) Pengukuran lingkar kepala; 4) Pengukuran lingkar lengan. Sedangkan untuk deteksi dini penyimpangan perkembangan adalah dengan menanyakan kepada orang tua kemampuan yang telah dicapai oleh anak berdasarkan usia seperti pada buku KIA. Menurut dr.Yulia Suherlina (2011) deteksi penyimpangan perkembangan oleh kader posyandu diantaranya apabila si bayi perkembangannya telah sesuai dengan usianya,maka disarankan untuk dating kembali pada usia12 bulan. Bila terlambat 1 aspek perkembangan, misalnya, gerakan kasar, maka ibu-bapak dan pengasuh akan diberikan contoh rangsangan yang dapat dilakukan di rumah dan dipantau selama satu bulan. Apabila bayi mengalami keterlambatan lebih dari satu aspek perkembangan dan satu tingkatan umur, maka oleh kader pasti akan dirujuk ke petugas kesehatan. Selanjutnya, akan dilakukan pemeriksaan perkembangan dan pertumbuhan bayi tersebut. Langkah berikutnya akan ditentukan sesuai kondisi bayi tersebut (Kemendiknas. 2011). Dengan kemampuan kader kesehatan tersebut diatas, maka kader berkewajiban melakukan kunjungan rumah pada bayi atau balita yang berat badannya tidak naik atau tetap 2 kali penimbangan berturut-turut atau memberikan stimulasi pada bayi atau anak yang mengalami keterlambatan perkembangan. Dengan demikian akan terdeteksi secara dini adanya penyimpangan pertumbuhan pada anak. Hal ini didukung oleh hasil penelitian Wahyutomo, AH (2010) yang mengatakan ada hubunganyang bermakna antara frekuensi pelatihan yang diperoleh oleh kader posyandu dengan pemantauan tumbuh kembang balita $(\mathrm{p}=0,003, \mathrm{OR}=3,000)$. Tujuan dari suatu pelatihan ialah mengubah perilaku individu atau masyarakat dibidang kesehatan. Diharapkan semakin banyak kader mengikuti pelatihan maka akan mendapatkan ilmu, ide, gagasan dan wacana baru terutama dalam bidang kesehatan yang diharapkan dapat diterapkan untuk dirinya dan disebarkan untuk masyarakat disekelilingnya yang datang kepelayanan posyandu. Sejalan dengan hasil penelitian Aticeh, dkk (2015) yang berjudul Pengetahuan Kader Meningkatkan Motivasi Dalam Melakukan Deteksi Dini Tumbuh Kembang Balita, mengatakan pengetahuan secara signifikan dapat mempengaruhi timbulnya minat dan motivasi seseorang dalam melakukan kegiatan. Kurangnya pengetahuan kader dalam hal stimulasi deteksi dini tumbuh kembang terjadi karena tidak adanya pelatihan tentang SDIDTK dan kurangnya pendidikan kader.

\section{Diskripsi pelaksanaan stimulasi dan deteksi dini tumbuh kembang anak berdasarkan pada buku KIA oleh kader posyandu}

Kelurahan Dukuh Menanggal mempunyai wilayah yang dibagi menjadi 9 RW. Setiap RW mempunyai 1-3 posyandu. Sehingga total jumlah posyandu yang ada di wilayah Kelurahan Dukuh Menanggal berjumlah 13 Posyandu. Satu posyandu mempunyai 5 orang kader kesehatan. 
Sehingga kader yang ada di Kelurahan Dukuh Menanggal seluruhnya berjumlah 65 orang. 1 Posyandu mempunyai bayi dan balita minimal 25 bayi balita dan maksimal mempunyai 65 bayi balita. Di wilayah Kelurahan Dukuh Menanggal juga mempunyai 1 pos BKB yang terletak di Posyandu Anggrek Merpati 12 yang mempunyai jumlah balita paling banyak yaitu 65 bayi dan balita. Dan 1 pos PAUD.

Jumlah bayi dan balita yang hanya 25 - 65 orang, sebenarnya bukan suatu alasan untuk tidak melakukan stimulasi dan deteksi dini pada saat buka posyandu. Dalam buku Pedoman Umum Pengelolaan Posyandu (Depkes RI, 2006) mengatakan bahwa idealnya 1 posyandu melayani 80 - 100 bayi dan balita.

Dari hasil wawancara mendalam didapatkan informasi bahwa sebagian besar kader kurang memahami kegiatan posyandu di meja 4. Sepengetahuan mereka kegiatan di meja 4 adalah memberitahu orang tua hasil penimbangan dan melakukan penyuluhan jika ditemukan penyimpangan pertumbuhan. Sedangkan menilai perkembangan balita sesuai umur berdasarkan buku KIA tidak dilakukan, sehingga kader jarang menemukan sedini mungkin gejala penyimpangan dari perkembangan. Sedikitnya jumlah balita yang ada seharusnya bisa mengoptimalkan kegiatan yang ada di posyandu, dan menjadikan posyandu yang ada menjadi posyandu terintegrasi dengan penambahan kegiatan-kegiatan baru seperti BKB didalamnya. Sehingga jika ditemukan penyimpangan tumbuh kembang pada anak, bisa segera melakukan rujukan untuk mendapatkan intervensi.

Beberapa alasan mengapa tidak melakukan kegiatan stimulasi tumbuh kembang anak pada saat jam buka posyandu diantaranya adalah kurangnya pengetahuan tentang kegiatan stimulasi yang ada dalam buku KIA, tidak adanya alat APE di posyandu, dan sudah ada pos PAUD. Kader hanya sekedar menanyakan kepada orang tua kepandaian apa yang sudah dicapai oleh sang anak, itupun tidak ditanyakan secara rutin kepada ibu bayi dan balita yang datang ke posyandu. Kemudian memberikan penyuluhan apa adanya berdasarkan sepengetahuan mereka tentang stimulasi.

Berdasarkan hasil observasi peneliti di tempat posyandu, kegiatan deteksi pertumbuhan yang dilakukan kader sudah cukup baik yaitu pengukuran berat badan, pengukuran tinggi badan anak dan lingkar kepala. Pada pengukuran berat badan, alat yang digunakan oleh kader adalah tipe
Salter spring balance digunakan pada balita yang belum bisa berdiri, dan tipe Bathroom scale untuk anak yang sudah bisa berdiri sendiri, atau menimbang anak bersama ibunya. Sedangkan untuk mengukur panjang/ tinggi badan, kader menggunakan alat ukur crown-heel length pada bayi dan anak usia kurang dari 2 tahun, dan untuk anak yang sudah berdiri sendiri menngunakan vertical measures (microtoise). Untuk pengukuran lingkar kepala dilakukan dengan cara melingkarkan pita pengukur fleksibel dari bahan tidak elastik melalui bagian paling menonjol di bagian kepala belakang (protuberantia occipitalis) dan dahi (glabella). Menurut dr. Kartika Ratna Pertiwi, pengukuran ini penting untuk menilai apakah lingkar kepala anak berlebih seperti pada anak yang menyandang hidrosefalus atau terlalu kecil, misalnya, pada Crouzon Syndrome yaitu gangguan yang menyebabkan penutupan ubun-ubun dan penyatuan tulang tengkorak yang terlalu cepat. Kurva yang digunakan untuk menilai pertumbuhan pada lingkar kepala adalah kurva Nellhaus yang diperoleh dari 14 penelitian di dunia dan menyatakan bahwa tidak terdapat perbedaan bermakna antar suku bangsa, ras, maupun secara geografis.

Kemudian hasilnya dicatat dalam buku KIA atau KMS. Jika ditemukan masalah tentang berat badan anak yang tetap atau tidak naik dan tinggi badan anak yang kurang, kader posyandu memberikan penyuluhan tentang PMT sesuai dengan pengetahuannya. Pengukuran lingkar lengan atas anak tidak pernah dilakukan. Pengukuran Lingkar Lengan Atas (LLA) menggambarkan tumbuh kembang jaringan lemak dibawah kulit dan otot yang tidak banyak terpengaruhi oleh keadaan cairan tubuh dibandingkan dengan berat badan. LLA lebih sesuai untuk dipakai menilai keadaan gizi/ tumbuh kembang anak kelompok usia prasekolah (1-5 tahun) (dr.Kartika R.P). Pengukuran LLA di posyandu jarang dilakukan, hal ini karena pengetahuan penentuan status gizi yang kader ketahui hanya pengukuran $\mathrm{BB}$, TB dan Lingkar Kepala. Padahal kegiatan ini sebenarnya mudah dilakukan dan alatnya murah, hanya dengan menggunakan alat pita ukur non elastis. Hal tersebut dikarenakan belum ada sosialisasi pelaksanaan pengukuran lingkar lengan atas anak, dan tidak tersedianya alat. Pengukuran LLA selama ini diasumsikan hanya untuk pengukuran status gizi pada ibu hamil. 
Belum sepenuhnya dilaksanakan sosialisasi tentang buku KIA dan tidak semua bayi dan balita mempunyai buku KIA, membuat kegiatan stimulasi deteksi dini tumbuh kembang anak yang ada didalamnya belum diketahui oleh semua kader posyandu dan ibu bayi balita. Buku KIA diterbitkan oleh Departemen Kesehatan Republik Indonesia bekerjasama dengan JICA. Buku KIA merupakan bagian dari "Gerakan Nasional Pemantauan Tumbuh Kembang Anak" yang dicanangkan oleh Presiden Republik Indonesia pada 24 Juli 2005. Buku ini memberikan pedoman yang lengkap dan jelas tentang kesehatan ibu dan anak. Penggunaan Buku Kesehatan Ibu dan Anak (Buku KIA) ditingkat keluarga (home based) dimaksudkan agar keluarga mempunyai buku catatan dan informasi kesehatan dan tumbuh kembang anak.Setelah anak lahir, buku tersebut menjadi milik anak sekaligus untuk pembinaan perkembangan anak sejak usia dini (earlychild development).

Buku KIA biasanya diberikan oleh setiap ibu hamil yang datang ke puskesmas atau ke pusat pelayanan kesehatan yang lain. Di dalam buku ini memang tercantum banyak sekali hal yang berguna mulai sejak ibu hamil hingga tumbuh kembang anak sampai berusia enam tahun.Sayangnya, kadang ada saja ibu yang belum mengetahui keberadaan buku ini, meskipun tinggal di kota besar. Guna membantu penyebaran buku ini pada setiap ibu hamil, pemerintah telah memberikan softcopy dan dapat diunduh melalui situs

http://www.depkes.go.id/downloads/jica/kia.htm.

(Hary Kuncoro, 2016)

Kesadaran kader posyandu melakukan rujukan ketika menemukan penyimpangan pertumbuhan dan perkembangan pada anak di sekitar lingkungan tempat tinggal mereka sudah baik. Meskipun demikian menurut data dari Dinkes Jatim (2011) yang dikutip oleh Yolanda Cicilia Eka, dkk (2014) menyatakan pemeriksaan deteksi dini tumbuh kembang anak di Jawa Timur pada tahun 2011 masih 69\%, hal ini masih jauh dari apa yang ditargetkan yaitu $80 \%$, sehingga perlu inovasi dan meningkatkan pengetahuan serta ketrampilan kader posyandu untuk meningkatkan cakupan agar dapat ditanggulangi apabila terjadi masalah atau keterlambatan tumbuh kembang pada anak balita. Kader adalah garda paling depan dalam hal membantu pelayanan kesehatan kepada masyarakat, dengan memberikan pelatihan yang intensif pada kader tentang stimulasi dan deteksi dini tumbuh kembang anak akan banyak membantu petugas kesehatan yang dalam hal ini Bidan penanggung jawab wilayah dalam hal memantau kesehatan bayi dan anak-anak di posyandu.

Hasil interview trianggulasi dengan Bidan Koordinator wilayah mengatakan pengetahuan kader tentang stimulasi yang ada didalam buku KIA ada yang tahu dan ada yang belum tahu, walaupun demikian di luar jam buka posyandu, beberapa kader tidak jarang menemukan penyimpangan tumbuh kembang pada anak, dan mereka akan melakukan rujukan ke Bidan atau Puskesmas Gayungan. Oleh karena itu penting sekali dalam memberikan pelatihan bagi kader kesehatan tentang bagaimana deteksi dini pertumbuhan dan perkembangan pada anak. Sehingga cakupan deteksi dini penyimpangan tumbuh kembang dapat tercapai, dan akan meningkatkan kunjungan ibu bayi dan balita ke posyandu dikarenakan adanya kegiatan deteksi dini tumbuh kembang yang dilakukan oleh kader posyandu.

\section{KESIMPULAN}

\section{Pengetahuan Kader Posyandu Tentang Stimulasi Tumbuh Kembang Anak}

Pengetahuan kader posyandu tentang kegiatan stimulasi tumbuh kembang anak yang terdapat dalam buku KIA tergolong kurang. Pengetahuan kader tentang stimulasi tumbuh kembang sebagian besar diasumsikan dengan pemberian makanan untuk pertumbuhan. Hal tersebut dikarenakan kurangnya sosialisasi tentang kegiatan yang ada dalam buku KIA. Masih banyak orang tua bayi dan balita yang datang ke posyandu tidak membawa buku KIA melainkan membawa KMS. Belum adanya pelatihan tentang bagaimana memberikan stimulasi tumbuh kembang anak juga berpengaruh pada pengetahuan mereka yang kurang tentang stimulasi, tidak tersedianya APE di posyandu, sudah ada pos PAUD, membuat kader posyandu beranggapan bahwa kegiatan stimulasi lebih tepat jika dilakukan di pos PAUD tersebut.

\section{Pengetahuan Kader Posyandu Tentang Deteksi Dini Tumbuh Kembang Anak}

Sebagian besar asumsi pengetahuan kader tentang deteksi dini penyimpangan pertumbuhan dan deteksi dini penyimpangan perkembangan 
adalah sama. Deteksi dini pertumbuhaan yang dilakukan pada saat jam buka posyandu hanyalah pengukuran berat badan, pengukuran tinggi badan anak dan pengukuran lingkar kepala. Sedangkan pengukuran lingkar lengan atas tidak dilakukan dengan alasan belum pernah disosialisasikan kegiatan tersebut, hanya dilakukan pada ibu hamil. Untuk deteksi dini penyimpangan perkembangan, kader sesekali menanyakan kepandaian apa yang telah dimiliki sang anak berdasarkan usianya dan langsung dilakukan rujukan jika ditemukan penyimpangan.

\section{Pelaksanaan stimulasi dan deteksi dini tumbuh kembang anak berdasarkan pada buku KIA oleh kader posyandu}

Kegiatan stimulasi dan deteksi dini tumbuh kembang anak seperti yang terdapat dalam buku KIA, tidak sepenuhnya dilaksanakan dengan baik. Pengetahuan kader tentang isi dari buku KIA yang terdapat kegiatan cara menstimulasi tumbuh kembang anak masih minim sekali. Kegiatan deteksi dini penyimpangan tumbuh kembang berdasarkan pada pengalaman budaya yang ada. Kader seharusnya bertanya tentang kepandaian yg telah dicapai oleh anak berdasarkan usianya kemudian mencontreng pada kolom yang telah disediakan dalam buku KIA. Jika ditemukan penyimpangan pada kepandaian anak, kader bisa memberikan konseling kepada orang tua tentang bagaimana cara merangsang kepandaian anak dirumah. Jika dari hasil observasi anak masih tertinggal perkembangannya maka dilakukan rujukan ke Bidan atau Puskesmas Gayungan..

Sedangkan kegiatan deteksi dini pertumbuhan, sudah dilaksanakan dengan baik. Deteksi dini yang dilakukan adalah pengukuran $\mathrm{BB}$, TB dan lingkar kepala. Beberapa masalah yang ada adalah kurangnya pengetahuan tentang kegiatan stimulasi tumbuh kembang dalam buku KIA, tidak tersedianya alat pengukuran lingkar lengan atas, tidak tersedianya APE. Tetapi langkah yang diambil kader kesehatan jika menemukan penyimpangan tumbuh kembang anak sudah tepat yaitu melakukan rujukan pada bidan atau fasilitas kesehatan puskesmas terdekat.

\section{DAFTAR PUSTAKA}

Aticeh, dkk. (2015). Pengetahuan kader Meningkatkan Motivasi Dalam Melakukan Deteksi Dini Tumbuh Kembang Balita .
ejurnal.poltekkesjakarta3.ac.id/index.php/J ITEK/article/view/95/88. Diunggah tanggal 6 Mei 2016.

Eka, YC, dkk. (2014). Faktor-Faktor Yang Mempengaruhi Perilaku Kader KIA Dalam Deteksi Dini Perkembangan Balita Di Posyandu Wilayah Kerja Puskesmas Babat Lamongan. Fakultas Keperawatan UNAIR. Surabaya. journal.unair.ac.id. Diunggah Tanggal 15 Mei 2016.

Frankenburg, W.K., et al. .1992. The denver II: A major revision and

Soetjiningsih. 1995. Tumbuh Kembang Anak. EGC. Jakarta

Shonkoff, J.P. \& Philips, D.A. 2000. From neurons to neighborhoods: The science of early childhood development. Washington: National Research Council and Institute of Medicine

Sugiono. 2009. Memahami Penelitian Kulitatif. Bandung. Alfabeta.

Saputra, L. 2014. Pengantar Asuhan Neonatus, Bayi dan Balita. Jakarta. Binarupa Aksara.

Soetjiningsih. 2003. Perkembangan Anak dan Permasalahnnya. Jakarta. EGC.

Sehat.link, 2014. 40\% Balita Alami Gangguan Bicara dan Bicara.

Suherlina, Yulia. 2011. Manfaat Deteksi Dini

Tumbuh Kembang. Kementeriaan

Pendidikan Nasional. Jakarta.

Suharmini, Tin, dkk. Pelatihan Karakteristik Dan Deteksi Tumbuh Kembang Anak Usia Dini Bagi Kader Posyandu Plus. Jurnal Inotek Volume 13 No.1 Februari. 2009. ISSN : 1441-3554. Universitas Negeri Yogyakarta.

Sukesi, N, dkk. Manajemen Penatalaksanaan Deteksi Dini Tumbuh Kembang Anak di Posyandu Kelurahan Manyaran. Jurnal Staff Pengajar STIKES Widya Husada Semarang Prodi DIII Keperawatan. Diunggah tanggal 2 Mei 2016. https://publikasiilmiah.ums.ac.id

Tim Dirjen Pembinaan Kesmas. 1997. Pedoman Deteksi Dini Tumbuh Kembang Balita. Jakarta. Depatemen Kesehatan RI.

Wahyutomo, AH. 2010.

HubunganKarakteristikDanPeran

KaderPosyanduDenganPemantauan

TumbuhKembangBalitaDiPuskesma

$s \quad$ Kalitidu-Bojonegoro. Tesis 
Program Pascasarjana Universitas Sebelas Maret Surakarta. Solo.

Wibawa, YA, dkk. Peran Kader Posyandu Dalam Pengaplikasian Stimulasi, Deteksi Dini Dan Intervensi Dini Tumbuh Kembang Anak Di Desa Pucungkerep Kecamatan Kaliwiro Kabupaten Wonosobo. Diunggah tanggal 2 Mei 2016. ejournal.stikesmuhgombon 